\title{
Geochemical characteristics and mode of occurrence of trace elements in coal at West Bokaro coalfield
}

\author{
Sk. Md. Equeenuddin ${ }^{1} \cdot$ Subhasish Tripathy $^{2} \cdot$ \\ Prafulla Kumar $\mathrm{Sahoo}^{3} \cdot$ Amit Ranjan ${ }^{2}$
}

Received: 30 December 2015/Revised: 1 August 2016/Accepted: 11 October 2016/Published online: 20 October 2016

(C) The Author(s) 2016. This article is published with open access at Springerlink.com

\begin{abstract}
The mineralogy and trace element contents in coals from the West Bokaro coalfield, which is the one of the biggest Gondwana coalfields of India, were studied to delineate enrichment of trace elements and their modes of occurrence. Elemental concentrations with reference to their crustal abundances indicated that coals are relatively enriched in As $(4.4-15.5 \mathrm{mg} / \mathrm{kg}), \mathrm{Cd}(0.3-3.0 \mathrm{mg} / \mathrm{kg}), \mathrm{Cu}(28.0-68.1 \mathrm{mg} / \mathrm{kg})$ and $\mathrm{V}(46.6-178.0 \mathrm{mg} / \mathrm{kg}) ;$ depleted in Co $(10.8-28.4 \mathrm{mg} /$ $\mathrm{kg})$, Mn (7.6-483.4 mg/kg), Ni (13.0-31.6 mg/kg), Cr (14.2-85.5 mg/kg) and Zn (5.25-70.4 mg/kg). The concentration of $\mathrm{As}, \mathrm{Cd}, \mathrm{Co}, \mathrm{Cu}$ and $\mathrm{V}$ were higher than the average values of world and Indian coals. Mineralogical study carried out by $\mathrm{X}$-ray diffraction shows that quartz and kaolinite occur as dominant mineral phases in this coal. Fourier transform infrared spectroscopy pattern suggests organic structures primarily containing aromatic nuclei, aliphatic side chain and some oxygen containing groups. The modes of occurrence of trace elements present in these coals have been determined through statistical approach. Both $\mathrm{Cu}$ and $\mathrm{Cr}$ are more closely associated with mineral matter, whereas Co is dominantly present with its organic form. The concentrations of $\mathrm{Cd}, \mathrm{Mn}, \mathrm{Ni}, \mathrm{Zn}, \mathrm{As}$ and $\mathrm{V}$ have apparently occur in both organic and inorganic constituents. This study would be helpful to assess the potential environmental impacts during mining and combustion of this coal.
\end{abstract}

Keywords Mineralogy $\cdot$ Organic group $\cdot$ Trace elements $\cdot$ Coal $\cdot$ West Bokaro

\section{Introduction}

Studies on trace elements in coals have attracted much scientific interest worldwide, not only because of detrimental health hazards and related environmental problems by utilization of coal (Finkelman 1995; Dai et al. 2012a; Equeenuddin 2015), but also because of economically valuable elements contained in the coal and coal bearing

Sk. Md. Equeenuddin

md_equeen@yahoo.co.in

1 Department of Earth \& Atmospheric Sciences, National Institute of Technology, Rourkela, Odisha 769008, India

2 Department of Geology and Geophysics, Indian Institute of Technology, Kharagpur, West Bengal 721302, India

3 Vale Institute of Technology, Boaventura da Silva, Belém, Pará 66055-090, Brazil strata (Seredin and Finkelman 2008; Dai et al. 2015; Franus et al. 2015). The concentrations, distribution and modes of occurrence of trace elements in coal is mainly influenced by geological factors like depositional environment and other physical and biogeochemical factors during its formation (Hower et al. 2007; Li et al. 2016). Dai et al. (2012b) attributed the enrichment of trace elements in Chinese coal to various processes which include sourcerock controlled, marine environment-controlled, hydrothermal fluid controlled (including magmatic-, low temperature hydrothermal fluid-, and submarine-exhalation controlled subtypes), groundwater-controlled, and volcanic-ash-controlled. The study of trace elements in coal provides information about depositional environment as well as it is important in anticipating the behavior of the toxic elements during coal cleaning, combustion, and leaching (Finkelman 1994; Wang et al. 2003). 
In India, coal is not only main source of energy, but also the foundation of country's economic and social development. Besides, India is the third largest coal producer next to China and the USA (World Energy Statistics 2014). According to Coal India Vision-2025, production of coal was about 6 million tons per year at the beginning of the 20th century and is expected to grow to $1267 \mathrm{Mt}$ by year 2024-2025. Thus, the interest on coal research in our country has been growing widely. The quantitative data on trace elements of various Gondwana coal (Mukherjee et al. 1981, 1988; Singh et al. 1983; Pareek and Bardhan 1985; Mohanty et al. 2001) and Tertiary coals (Mukherjee et al. 1981; Mukherjee and Srivastava 2005; Baruah et al. 2003; Sahoo et al. 2014) are available. However very few data on the modes of occurrence of trace elements are available in the West Bokaro coalfield, which is one of biggest Gondwana coalfields based on its areal extent, number and thickness of coal seams and reserves of coking coals (Pareek and Bardhan 1985). In the present study, coal samples from the West Bokaro coalfield were studied with the aim for investigating their mineralogy, organic functional groups, and total concentration of metals and their modes of occurrence. This paper may advance the knowledge on the trace elements in the coal seams and help in accessing the environmental impacts of this coalfield.

\section{Geological setting}

West Bokaro coalfield, located in Hazaribad district, Jharkhand, forms a part of Son-Damodar basin. The total reserve is about 5103 million tonnes with medium grade coking properties. It is a narrow basin with a maximum width of $11.3 \mathrm{~km}$, from north to south and extends over a length of about $64 \mathrm{~km}$ from Chirudih $\left(23^{\circ} 46^{\prime}\right.$ and $\left.86^{\circ} 05^{\prime}\right)$ on the east to Kodme $\left(23^{\circ} 44^{\prime}\right.$ and $\left.85^{\circ} 25^{\prime}\right)$ on the west. The geological map of the West Bokaro coalfield is given in Fig. 1. The Archaean rocks form the basement for deposition of the sediments of the West Bokaro basin. The basin is characterized by deposition of glacial Talchir-boulder Formation at the base followed by fluvial sedimentation of conglomerate, grit, sandstones, shales and coal of Karharbari and Barakar formations, ironstone shale, cyclic sedimentation of sandstones, shales and coal of Raniganj Formation, psammopelitic rocks of Panchet Formation, and sandstone and shale of Supra-Panchet Group occurs at the top (Gupta et al. 2002). This Permian coal of bituminous rank is mainly associated with the Barakar Formation. West Bokaro coalfield consists of 13 number of coal seam of various thickness. Among them seam III, IV, V, VA, VI and VII are the most persistent and productive. Large scale intrusions of lamproitic and lamprophyric types of dykes and sills are observed in the Barakar Formation (Gupta et al. 2002). The ash and moisture content in the West Bokaro coals varies from $23 \%$ to $33.78 \mathrm{wt} \%$ and $1.28 \%$ to $2.09 \mathrm{wt} \%$ respectively. The volatile content of these coals varies between $22.85 \%$ and $25.52 \mathrm{wt} \%$ while the fixed carbon ranges between $38.7 \%$ and $52.06 \mathrm{wt} \%$. Ultimate analysis shows that carbon content varies from $8.21 \%$ to $85.46 \mathrm{wt} \%$, hydrogen from $0.19 \%$ to $5.1 \mathrm{wt} \%$, total sulphur from 0.78 to $0.9 \mathrm{wt} \%$, nitrogen from $1.2 \%$ to 1.58 wt $\%$, and oxygen from $6.82 \%$ to $8.29 \mathrm{wt} \%$ (Singh et al. 2015).

\section{Materials and methods}

Coal samples were collected from the Topa (Seam III, IV, V, VI and VII), Kedla (Seam IV, V, VI and VII) and Parej collieries (Seam III and IV) located in the West Bokaro coalfield by channel method. Samples were air dried, powdered and sieved $(-63 \mu \mathrm{m})$ immediately and kept in sealed polyethylene packets for nearly a month in the laboratory for further study. Mineralogy of coal was studied by X-ray diffraction (XRD) (Philips PW-1830) using whole coal at room temperature. The XRD data were collected at very slow scan of $2 \%$ min with a step size of $0.05^{\circ}$ in a wide range of Bragg's angle $2 \theta$ $\left(10^{\circ} \leq 2 \theta \leq 70^{\circ}\right)$ using $\mathrm{Cu}-\mathrm{K} \alpha$ radiation $(\lambda=1.5418 \AA)$. The X-ray tube was operated at $40 \mathrm{kv}$ and $40 \mathrm{~mA}$. Bulk chemical analysis of the coal samples was carried out using Atomic Absorption Spectrophotometer (AAS) (PerkinElmer Analyst200) following the digestion of whole coal sample. Microwave acid digestion of coal (1 g) using $\mathrm{HNO}_{3}(8 \mathrm{~mL}), \mathrm{HF}(2 \mathrm{~mL})$ and $\mathrm{H}_{2} \mathrm{O}_{2}(1 \mathrm{~mL})$ was done at $200{ }^{\circ} \mathrm{C}$. Whole coal samples were used as there should not be any loss of significant concentration of elements bound with organic matter. Standard reference material of subbituminous coal (SRM 1635) was used to measure the accuracy of the AAS result, and analytical error was found to be within $\pm 10 \%$. The organic functional groups present in coal were determined by Fourier transform infrared (FTIR) spectroscopy on pressed pellets of whole coal mixed with $\mathrm{KBr}$. The FTIR spectra of whole coal were obtained in the wavenumber range $400-4000 \mathrm{~cm}^{-1}$ using NEXUS 870 FTIR (Thermo Nicolet) in humid-free atmosphere at room temperature.

\section{Results and discussion}

\subsection{Mineralogy}

The XRD pattern of the whole coal from the West Bokaro coal is given in Fig. 2. This indicates that quartz and kaolinite as dominant mineral phases in coal while siderite, 


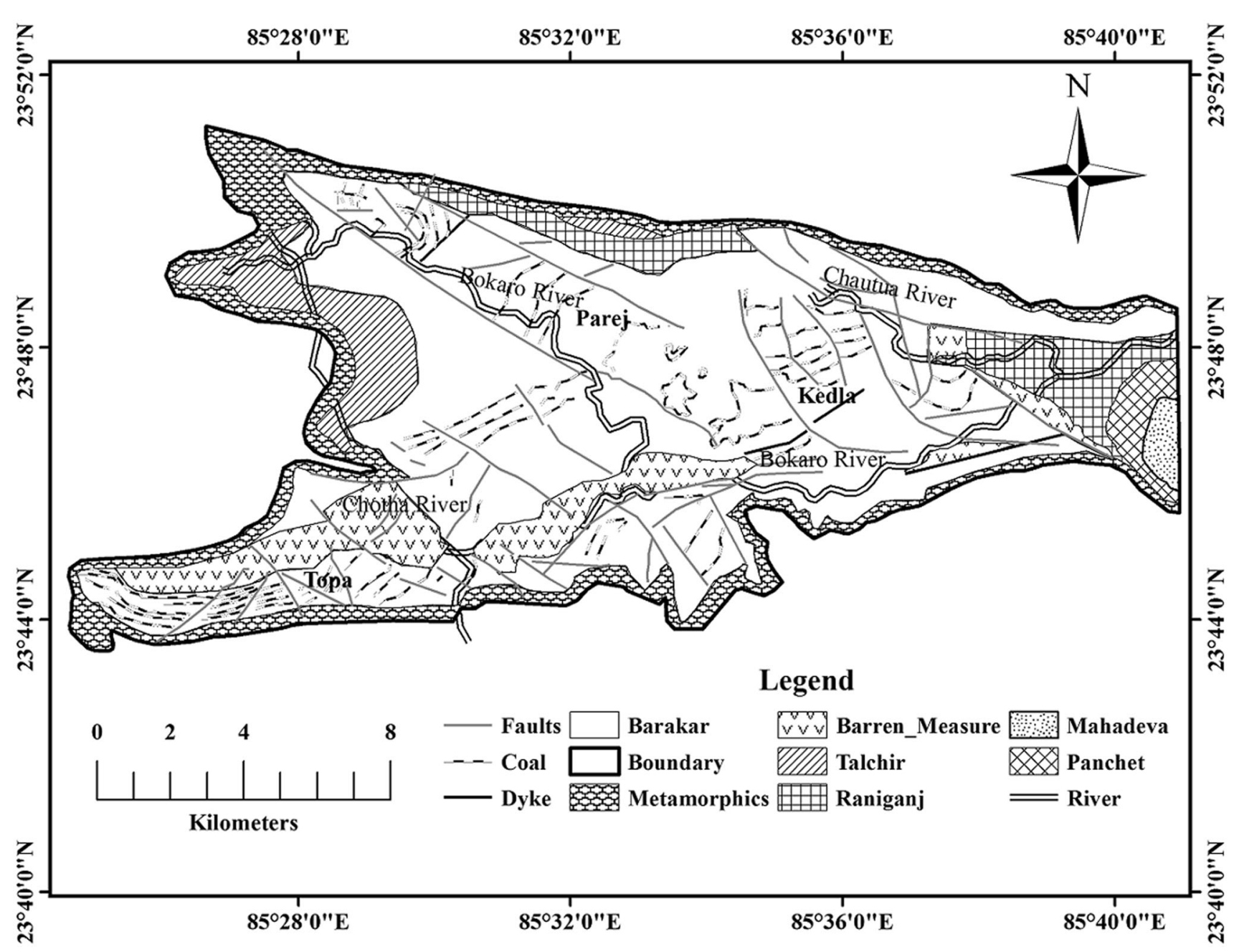

Fig. 1 Geological map of the West Bokaro Coalfield

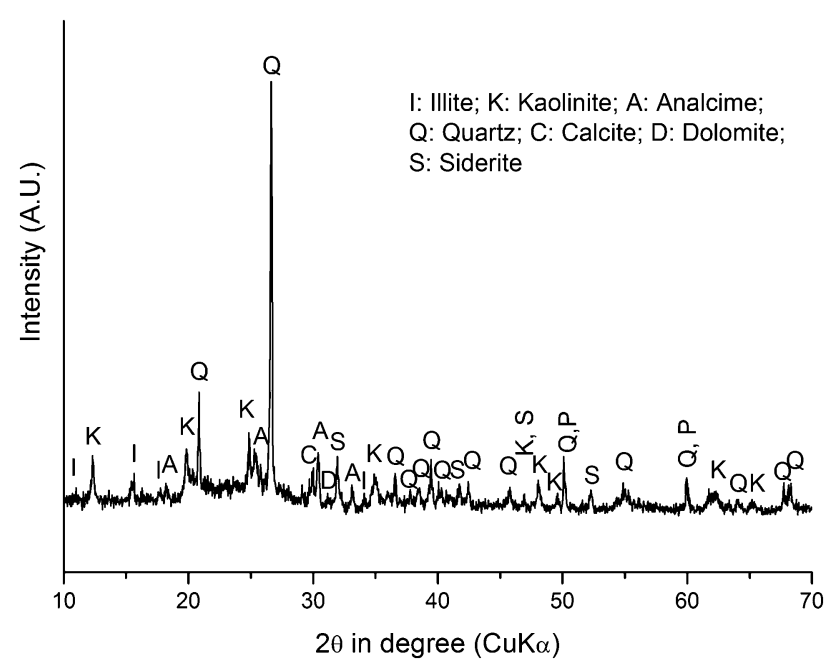

Fig. 2 XRD pattern of the whole coal from seam IV of Parej

illite and analcime occur as intermediate phases. Calcite, dolomite and pyrite occur in minor amounts in this coal. The FTIR spectrum of coal is given in Fig. 3. Most of the

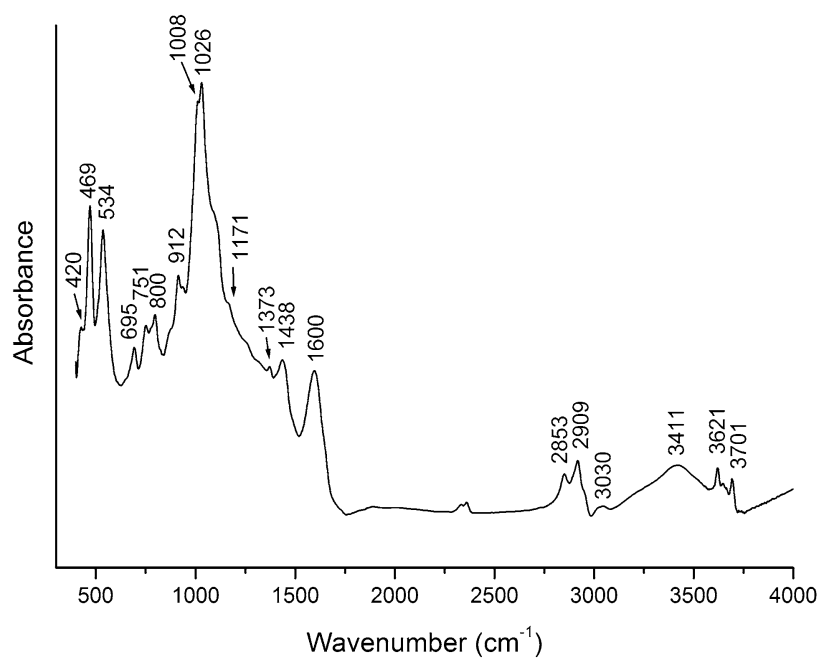

Fig. 3 FTIR spectrum of the whole coal from seam VII of Topa peaks between 1100 and $400 \mathrm{~cm}^{-1}$ can be assigned to clay minerals such as kaolinite, illite and the montmorillonite group. The distinct peak at 1171, 1026, 1008, 533 and 
$469 \mathrm{~cm}^{-1}$ in the FTIR pattern can be attributed to these mineral groups. The $\mathrm{Si}-\mathrm{O}-\mathrm{Si}$ stretching vibration causes absorption at 1026 and $1008 \mathrm{~cm}^{-1}$. The $\mathrm{Si}-\mathrm{O}$ bending vibration contributes to the strong absorption at 533 and $469 \mathrm{~cm}^{-1}$. Both these peaks can also be due to the presence of ionic sulphates. A weak absorption at $1171 \mathrm{~cm}^{-1}$ in the FTIR spectra can be ascribed to the presence of mineral quartz. A weak absorption due to pyrite at $420 \mathrm{~cm}^{-1}$ is also observed. West Bokaro coal shows that $\mathrm{O}-\mathrm{H}$ stretching vibrations are situated at 3701 and $3621 \mathrm{~cm}^{-1}$. The peaks for O-H groups at $3600-3800 \mathrm{~cm}^{-1}$ appear to be for those associated with clay minerals (Georgakopoulos et al. 2003). As observed by XRD, FTIR also confirmed the dominant of quartz and clay minerals like kaolinite and illite.

\subsection{Organic functional groups in coal}

Information on various organic groups present in coal is very important because most elements bind with them (Swaine 1995), adsorb and/or form various complexes with carboxyl and phenol groups (Murakami et al. 1995). FTIR is widely used to delineate carbohydrogenated structures (aromatic and aliphatic) and heteroatomic functions (mainly oxygenated), as well as detect various minerals (Ibarra et al. 1996; Georgakopoulos et al. 2003).

FTIR spectra bands were assigned based on the standard patterns of coal (Guo et al. 1996; Saikia et al. 2007). A broad absorption band is observed at $3411 \mathrm{~cm}^{-1}$ in the coal, which may be due to the presence of $\mathrm{N}-\mathrm{H}$ and $\mathrm{O}-\mathrm{H}$ groups. The weak peak at $3030 \mathrm{~cm}^{-1}$ is due to aromatic CH stretching. The sharp peak of medium intensity at 2909 and $2853 \mathrm{~cm}^{-1}$ may be assigned to aliphatic and alicyclic $\mathrm{CH}_{3}, \mathrm{CH}_{2}$ and $\mathrm{CH}$ groups although the major contribution is expected to be due to $\mathrm{CH}_{2}$ groups. The intensity of peak at $2909 \mathrm{~cm}^{-1}$ is greater than the peak $2853 \mathrm{~cm}^{-1}$ indicates the presence of long aliphatic chains in the coal. The sharp and strong peak around $1600 \mathrm{~cm}^{-1}$ is assigned to aromatic $\mathrm{C}=\mathrm{C}$, vinylic $\mathrm{C}=\mathrm{C}$ and possibly due to other $\mathrm{O}$-containing functional groups. The oxygen containing functional groups found in coal specifically include phenols and alcohols, ethers, carboxylic acid and carbonyls. A strong band at $1438 \mathrm{~cm}^{-1}$ was observed, and it is mostly due to $\mathrm{CH}_{3}$ asymmetric deformation and $\mathrm{CH}_{2}$ group in bridges but may also be partly due to aromatic $\mathrm{C}=\mathrm{C}$ and strongly hydrogen bonded $\mathrm{O}-\mathrm{H}$ groups. The band at $1373 \mathrm{~cm}^{-1}$ is mainly caused due to $\mathrm{CH}_{3}$ symmetric deformation while $\mathrm{CH}_{3}$ and $-\mathrm{CH}_{2}$ in cyclic structures may also partially contribute to this band. Intensity of this peak is lower than the peak at $1438 \mathrm{~cm}^{-1}$ indicating that the methylene as long side chains. The band between 912 and $751 \mathrm{~cm}^{-1}$ has been assigned to aromatic structures. The peak band at $695 \mathrm{~cm}^{-1}$ appears in the coal could possibly be due to C-S bond. These absorption bands are most useful in determining the aromatic ring structure of a coal.

\subsection{Trace elements in coal}

\subsubsection{Concentration of metals and their enrichment}

Concentrations of metals in West Bokaro coal are given in Table 1. Manganese has the maximum concentration $(7.6-483.4 \mathrm{mg} / \mathrm{kg})$ in coal which is followed by $\mathrm{V}$ (46.6-178.0 mg/kg), Cu $\quad(28.0-68.1 \mathrm{mg} / \mathrm{kg}), \quad \mathrm{Cr} \quad(14.2-$ $85.5 \mathrm{mg} / \mathrm{kg}), \mathrm{Zn}(5.25-70.4 \mathrm{mg} / \mathrm{kg}), \mathrm{Ni}(13.0-31.6 \mathrm{mg} / \mathrm{kg})$, Co $(10.8-28.4 \mathrm{mg} / \mathrm{kg})$, As $(4.4-15.5 \mathrm{mg} / \mathrm{kg})$ and $\mathrm{Cd}$ $(0.3-3.0 \mathrm{mg} / \mathrm{kg})$. Analysis result for different elements in coal shows that average concentrations of $\mathrm{Ni}, \mathrm{Cr}$ and $\mathrm{Zn}$ are much below than the Indian coal average where as much higher than that of world coal average (Yudovich and Ketris 2005, 2006). In case of Mn though the concentration varies widely; most of the samples recorded lower value than the Indian and world average. The concentration of As is also much above the Indian average concentration in most of the sample though in some coal it exceeds the world average. The concentrations of $\mathrm{Cd}$, $\mathrm{Co}, \mathrm{Cu}$ and $\mathrm{V}$ are found to be much higher than that of Indian and World average.

Enhancement of many trace metals in coal can be attributed to geological and geochemical processes during its formation as well as through various epigenetic processes (Dai et al. 2012b). The extent to which coal becomes enriched with a given element can be indicated by calculating the ratio of concentration of element in coal to its average concentration into earth's crust. This ratio is defined as enrichment factor (EF) where "Clarke value" is an indicator of average concentration of an element in the earth crust. Enrichment factor less than one $(<1)$ implies depletion and more than one $(>1)$ indicates an enrichment of a trace element in the coal relative to its crustal abundance. It is quite clear that $\mathrm{Cd}$ and As have been distinctly enriched; $\mathrm{Cu}$ and $\mathrm{V}$ just enriched; while $\mathrm{Cr}, \mathrm{Cu}, \mathrm{Mn}, \mathrm{Ni}$ and $\mathrm{Zn}$ have been depleted as shown in Table 1. In comparison to the average concentration of metals in Lower Gondwana (Permian) coal of India, it is observed that West Bokaro coal has higher concentration of $\mathrm{Cu}, \mathrm{As}, \mathrm{Co}$ and $\mathrm{V}$.

\subsubsection{Mode of occurrence of metals}

The mode of occurrence of an element is a description of the manner in which an element is chemically bound in the host material. In coal, elements can be associated with the inorganic constituents (minerals) occurring as or in silicates, sulphides, oxides, carbonates, phosphates, sulphates, etc., or with the organic constituents in a variety of less well defined ways (Finkelman 1994). The element's modes of occurrence can strongly influence its behavior during 
Table 1 Trace Elements concentration at the West Bokaro coal in $\mathrm{mg} / \mathrm{kg}$ (whole coal basis) and compared with clark value (CV), Indian and world average, and lower Gondwana permian coal

\begin{tabular}{|c|c|c|c|c|c|c|c|c|c|c|}
\hline Sample & Ash $(\%)$ & $\mathrm{Cu}$ & $\mathrm{Cd}$ & Co & $\mathrm{Mn}$ & $\mathrm{Ni}$ & $\mathrm{Cr}$ & $\mathrm{Zn}$ & As & V \\
\hline $\mathrm{C}-1$ & 25.22 & 28.00 & 1.40 & 13.00 & 81.74 & 14.60 & 14.19 & 18.00 & 9.12 & 95.38 \\
\hline $\mathrm{C}-2$ & 23.56 & 36.40 & 2.40 & 11.80 & 54.50 & 13.00 & 18.42 & 5.25 & 8.94 & 111.90 \\
\hline $\mathrm{C}-3$ & 31.00 & 34.00 & 2.20 & 10.40 & 12.18 & 21.30 & 29.29 & 15.38 & 4.36 & 64.88 \\
\hline C-4 & 22.60 & 36.20 & 2.40 & 23.50 & 483.39 & 30.80 & 49.53 & 32.25 & 5.80 & 46.59 \\
\hline C-5 & 41.30 & 36.60 & 1.60 & 14.00 & 258.33 & 16.00 & 31.71 & 26.75 & 11.01 & 115.98 \\
\hline C-6 & 40.76 & 39.80 & 1.00 & 12.50 & 41.26 & 29.80 & 39.56 & 35.75 & 5.29 & 55.22 \\
\hline $\mathrm{C}-7$ & 23.36 & 49.60 & 0.40 & 23.40 & 9.30 & 28.90 & 44.70 & 37.00 & 5.83 & 78.68 \\
\hline C-8 & 40.80 & 40.40 & 1.30 & 16.10 & 49.91 & 31.60 & 39.26 & 70.38 & 7.37 & 74.97 \\
\hline C-9 & 50.62 & 68.10 & 3.00 & 10.80 & 46.11 & 24.10 & 85.47 & 16.38 & 7.73 & 98.13 \\
\hline C-10 & 37.66 & 60.20 & 1.20 & 15.20 & 41.13 & 18.60 & 38.35 & 40.00 & 10.91 & 159.90 \\
\hline C-11 & 40.98 & 65.00 & 1.40 & 14.60 & 7.60 & 23.20 & 52.85 & 23.00 & 15.47 & 178.02 \\
\hline C-12 & 27.82 & 40.60 & 1.00 & 28.40 & 31.40 & 25.20 & 32.60 & 20.26 & 11.60 & 148.50 \\
\hline C-13 & 23.40 & 43.80 & 0.30 & 21.10 & 151.83 & 23.00 & 41.22 & 18.75 & 4.98 & 64.43 \\
\hline $\mathrm{CV}^{\mathrm{a}}$ & - & 25.00 & 0.10 & 24.00 & 716.00 & 56.00 & 126.00 & 65.00 & 1.70 & 98.00 \\
\hline $\mathrm{EF}$ & & 1.78 & 5.03 & 0.68 & 0.13 & 0.41 & 0.31 & 0.42 & 4.90 & 1.01 \\
\hline World average $^{\mathrm{b}}$ & - & 17.00 & 0.2 & 6.00 & - & 16.00 & 17.00 & 29.00 & 9.00 & 29.00 \\
\hline Indian average $^{c}$ & - & 20.00 & 1.30 & 11.00 & 100.00 & 45.00 & 70.00 & 40.00 & 5.00 & 86.00 \\
\hline Lower Gondwana ${ }^{c}$ & & 26.8 & 2.4 & 14.0 & 73.0 & 25.3 & 44.7 & 29.8 & 4.80 & 52.1 \\
\hline
\end{tabular}

${ }^{a}$ Wedepohl (1995)

b Yudovich and Ketris (2005, 2006)

c Banerjee et al. (2000)

coal cleaning, weathering, leaching, combustion, and conversion. Some elements are present in coal both in organic and inorganic forms. These different modes of occurrence will cause the element to behave differently during coal cleaning and coal combustion, and thus will have different environmental and human health impacts (Finkelman 2004). Therefore, information on modes of occurrence of metals needs to be carefully considered.

Organic and/or inorganic affinity of an element has been related to its relation with ash content. An element in broad and general terms is considered organically bound if its concentration maintains almost the same level or decrease with increasing ash content, but it is considered inorganically bound if its concentration in coal increases with increasing ash content (Goodarzi 1988). The correlation coefficient among the metals is given in Table 2.

Copper $(r=0.59)$ and $\mathrm{Cr}(r=0.57)$ have significant positive correlation with ash yield. This indicates that they are associated mostly with the inorganic fraction. Copper is commonly associated with mineral matter in the form of chalcopyrite, which is most frequent accessory sulphide mineral in coal, and pyrite (Swaine 1995). However, occurrence of $\mathrm{Cu}$ with organic matter is reported from the low rank coal (Miller and Given 1978). Mode of occurrence of $\mathrm{Cr}$ in coal is not confirmed with certainty. Some of the studies reported the occurrence of $\mathrm{Cr}$ with organic matter, others concluded dual affinity and some ascertain regarding inorganic occurrence. Clay minerals (illite/mixed clay), pyrite and hematite were found to be the host for $\mathrm{Cr}$ (Finkelman 1994; Goodarzi 2002). Chromium appears to be associated with organic matter as $\mathrm{Cr}^{3+}$ and with chromite in some coal. Dendogram also reveals that $\mathrm{Cu}$ and $\mathrm{Cr}$ are highly correlated with each other and with ash content (Fig. 4).

In the West Bokaro coalfield, $\mathrm{Ni}$ shows very insignificant positive correlation $(r=0.11)$ with ash content. Therefore, it is inferred that Ni shows dual affinity. Singh et al. (1983) and Mukherjee et al. (1988) observed negative relationship for $\mathrm{Ni}$ with ash content and argued in favour of its affinity towards organic fractions in lower Gondwana coals in India. Swaine (1980) also concluded that there is enough evidence in support to link $\mathrm{Ni}$ with organic constituents although Swaine (1995) indicated that Ni might be associated with both the organic and inorganic components of coal. Very good correlation between $\mathrm{Ni}$ and $\mathrm{Cr}$ indicates that $\mathrm{Ni}$ might be associated partly with clay minerals $(r=0.49)$.

Sulphide minerals or fine-grained sulphides in clay and organic matter in coal are major source of Co in coal (Singh et al. 1983). However, Co in some coal may be associated with organic matter (Goodarzi 2002). In West Bokaro coal, Co has significantly negative correlation with 
Table 2 Pearson's correlation matrix among various trace elements and ash yield

\begin{tabular}{|c|c|c|c|c|c|c|c|c|c|c|}
\hline Item & Ash & $\mathrm{Cu}$ & $\mathrm{Cd}$ & $\mathrm{Co}$ & Mn & $\mathrm{Ni}$ & $\mathrm{Cr}$ & $\mathrm{Zn}$ & As & $\mathrm{V}$ \\
\hline Ash & 1.00 & & & & & & & & & \\
\hline $\mathrm{Cu}$ & $0.59 *$ & 1.00 & & & & & & & & \\
\hline $\mathrm{Cd}$ & 0.29 & 0.06 & 1.00 & & & & & & & \\
\hline $\mathrm{Co}$ & $-0.52 * *$ & -0.08 & $-0.49 * *$ & 1.00 & & & & & & \\
\hline $\mathrm{Mn}$ & -0.26 & -0.34 & 0.25 & 0.29 & 1.00 & & & & & \\
\hline $\mathrm{Ni}$ & 0.11 & 0.17 & -0.21 & 0.46 & 0.13 & 1.00 & & & & \\
\hline $\mathrm{Cr}$ & $0.57 *$ & $0.78 *$ & 0.29 & 0.01 & 0.05 & $0.49 * *$ & 1.00 & & & \\
\hline $\mathrm{Zn}$ & 0.28 & 0.09 & -0.34 & 0.17 & 0.03 & $0.63 *$ & 0.11 & 1.00 & & \\
\hline As & 0.30 & 0.39 & 0.00 & 0.00 & -0.18 & -0.38 & -0.02 & -0.10 & 1.00 & \\
\hline V & 0.28 & $0.50 * *$ & -0.05 & 0.00 & -0.37 & -0.43 & -0.01 & -0.16 & $0.94 * *$ & 1.00 \\
\hline
\end{tabular}

* Correlation is significant at the 0.05 level

** Correlation is significant at the 0.10 level

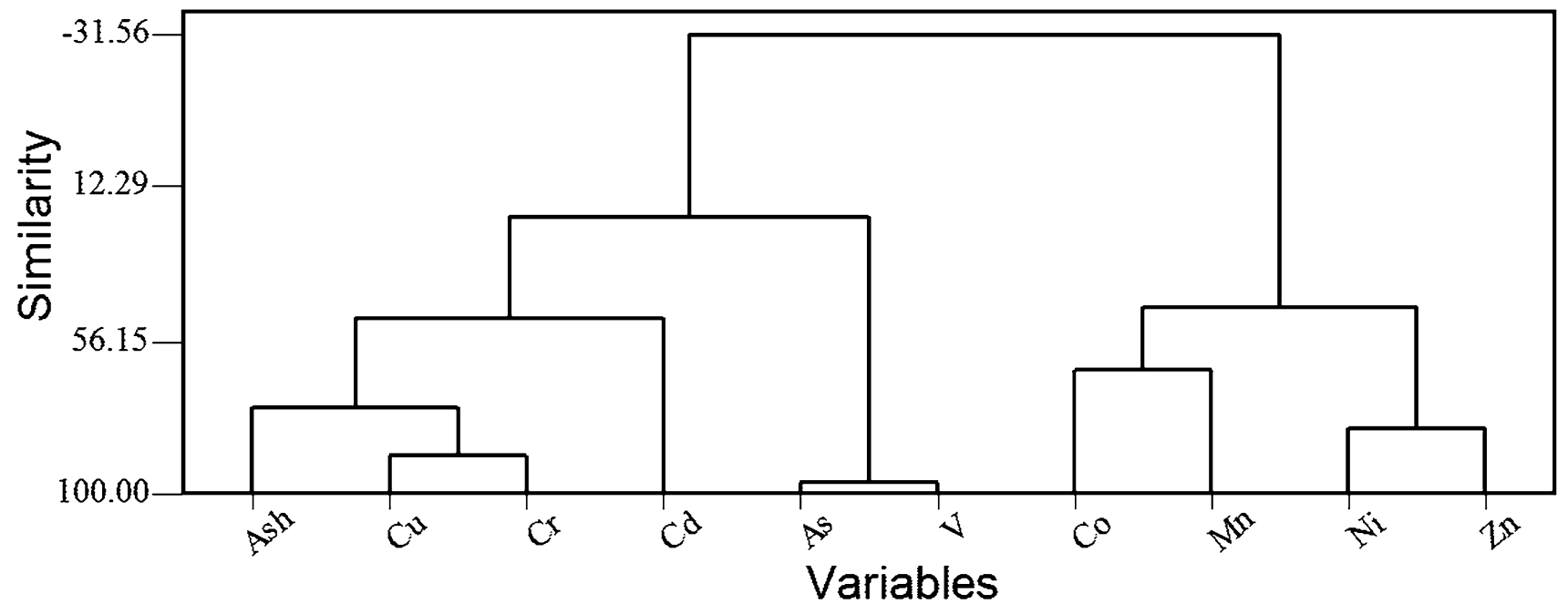

Fig. 4 Dendogram for ash content and trace elements prepared by Ward link method

ash yield, which ascertain its organic association. Manganese mainly occurs as solid solution in carbonates with small amounts associated with clay and pyrite (Finkelman 1994). In low rank coal Mn also found to be organically bound with carboxylic acid (Swaine 1990). Though Mn shows negative correlation with ash yield, it is not significant. Therefore, it reflects that $\mathrm{Mn}$ has dual affinity. Also Co shows significant positive correlation with $\mathrm{Ni}$ $(r=0.46)$, which is supposed to form organic complex. Negative relationship of $\mathrm{Co}$ and $\mathrm{Mn}$ with ash content, and proximity between $\mathrm{Co}$ and $\mathrm{Mn}$ is clearly depicted in dendogram (Fig. 4). Singh et al. (1983) and Mukherjee et al. (1988) suggested that both Co and Mn forming organomettalic complex in lower Gondwana coal.

Arsenic, $\mathrm{Cd}, \mathrm{Zn}$ and $\mathrm{V}$ show positive correlation with ash yield though not significantly. It indicates that they have dual affinity i.e. partly occur with mineral matter and partly with organic part of coal. Arsenic in coal commonly occurs with pyrite (Finkelman 1994; Dai et al. 2005), sometimes with clays (Swaine 1990), carbonates (Finkelman 1994) and arsenic bearing minerals such as realgar, orpiment and arsenopyrite (Ding et al. 2001). In some instances, organic association of As is also confirmed (Finkelman et al. 1990; Zhao et al. 1998). Cadmium occurs predominantly in sphalerite (Gluskoter and Lindahl 1973). However, occurrence of $\mathrm{Cd}$ in clay, carbonates and pyrite are also ascertained. In this study as there is no significant positive relation exists between $\mathrm{Cd}$ and $\mathrm{Zn}$; therefore, sphalerite as the source for $\mathrm{Cd}$ can be ignored. Zinc in most coal is generally associated with sulphides such as sphalerite and pyrite (Finkelman 1995; Hower et al. 2008). There are some studies which reported that $\mathrm{Zn}$ is 
association with aluminosilicate (Zhou et al. 2010). Zinc has very strong positive correlation with $\mathrm{Ni}$, which indicates that there may be possible occurrence with clay minerals along with organic complex. Organic association of $\mathrm{Zn}$ is also recorded (Karayigit et al. 2001). Fikelman (1981) observed that V mostly occurs with kaolinite and illite; Miller and Given (1978) showed the organic occurrence. Both organic and inorganic association of $\mathrm{V}$ is reported from the north-eastern coal of India and Hungarian coal (Szilagyi 1971; Mukherjee and Srivastava 2005). From Table 2 and dendogram it is well understood that $\mathrm{V}$ is closely associated with $\mathrm{As}$ and $\mathrm{Cu}$, which ascertain its dual affinity.

\section{Conclusions}

The study indicates that both As and $\mathrm{Cd}$ are highly enriched in West Bokaro coal though $\mathrm{Cu}$ and $\mathrm{V}$ slightly enriched. Cobalt, $\mathrm{Mn}, \mathrm{Ni}, \mathrm{Cr}$ and are depleted in coal. Concentration of $\mathrm{As}, \mathrm{Cd}, \mathrm{Co}, \mathrm{Cu}$ and $\mathrm{V}$ are higher than both world and Indian averages. Quartz and kaolinite occur as dominant mineral phases in this coalfield. FTIR pattern suggests organic structures primarily containing aromatic nuclei, aliphatic side chain and some oxygen containing groups. Both $\mathrm{Cu}$ and $\mathrm{Cr}$ are inferred to be associated mostly with mineral matter; whereas $\mathrm{Co}$ is dominantly present with its organic form. However, $\mathrm{Cd}, \mathrm{Mn}, \mathrm{Ni}, \mathrm{Zn}, \mathrm{As}$ and $\mathrm{V}$ have shown both organic and inorganic association.

Acknowledgments Authors acknowledge the Central Coalfield Limited for giving permission to carry the field work. Sincere thanks to Prof. H. K. Mishra for valuable suggestion during revision of the manuscript.

Open Access This article is distributed under the terms of the Creative Commons Attribution 4.0 International License (http://crea tivecommons.org/licenses/by/4.0/), which permits unrestricted use, distribution, and reproduction in any medium, provided you give appropriate credit to the original author(s) and the source, provide a link to the Creative Commons license, and indicate if changes were made.

\section{References}

Banerjee NN, Ghosh B, Das A (2000) Trace metals in Indian coals. Allied, New Delhi

Baruah MK, Kotoky P, Borah GC (2003) Distribution and nature of organic/mineral bound elements in Assam coals, India. Fuel 82:1783-1791

Dai S, Ren D, Tang Y, Yue M, Hao L (2005) Concentration and distribution of elements in Late Permian coals from western Guizhou Province, China. Int J Coal Geol 61:119-137

Dai SF, Jiang YF, Ward CR, Gu LD, Seredin VV, Liu HD, Zhou D, Wang XB, Sun YZ, Zou JH, Ren DY (2012a) Mineralogical and geochemical compositions of the coal in the Guanbanwusu Mine, Inner Mongolia, China: further evidence for the existence of an $\mathrm{Al}$ (Ga and REE) ore deposit in the Jungar Coalfield. Int $\mathrm{J}$ Coal Geol 98:10-40

Dai S, Ren D, Chou CL, Finkelman RB, Seredin VV, Zhou Y (2012b) Geochemistry of trace elements in Chinese coals: a review of abundances, genetic types, impacts on human health, and industrial utilization. Int J Coal Geol 94:3-21

Dai S, Seredin VV, Ward CR, Hower JC, Xing Y, Zhang W, Song W, Wang P (2015) Enrichment of U-Se-Mo-Re-V in coals preserved within marine carbonate successions: geochemical and mineralogical data from the Late Permian Guiding coalfield, Guizhou, China. Miner Depos 50:159-186

Ding Z, Zheng B, Zhang J, Long J, Belkin HE, Finkelman RB, Zhao F, Chen C, Zhou D, Zhou Y (2001) Geological and geochemical characteristics of high arsenic coals from endemic arsenosis areas in southwestern Guizhou Province, China. Appl Geochem 16:1353-1360

Equeenuddin SM (2015) Leaching of trace elements from India coal. J Geol Soc India 86:102-106

Finkelman RB (1981) Modes of occurrence of trace elements in coal, US Geological Survey, Open-file Rep 81-99, p 312

Finkelman RB (1994) Modes of occurrence of potentially hazardous elements in coal: levels of confidence. Fuel Process Technol 39:21-34

Finkelman RB (1995) Modes of occurrence of environmentally sensitive trace elements in coal. In: Swaine DJ, Goodarzi F (eds) Environmental aspects of trace elements in coal. Kluwer Academic, Dordrecht, pp 24-50

Finkelman RB (2004) Potential health impacts of burning coal beds and waste banks. Int J Coal Geol 59:19-24

Finkelman RB, Bragg LJ, Tewalt SJ (1990) Byproduct recovery from high-sulfur coals. Processing and utilization of high-sulfur coals, vol III. Elsevier, Amsterdam, pp 89-96

Franus W, Wiatros-Motyka MM, Wdowin M (2015) Coal fly ash as a resource for rare earth elements. Environ Sci Pollut R 22:9464-9474

Georgakopoulos A, Iordanidis A, Kapina V (2003) Study of low rank Greek coals using FTIR spectroscopy. Energy Sources 25:995-1005

Gluskoter HJ, Lindahl PC (1973) Cadmium: mode of occurrence in Illinois coal. Science 181:264-266

Goodarzi F (1988) Elemental distribution in coal seams at the Fording coal mine, British Columbia, Canada. Chem Geol 68:129-154

Goodarzi F (2002) Mineralogy, elemental composition and modes of occurrence of elements in Canadian feed-coals. Fuel 81:1199-1213

Guo Y, Renton JJ, Penn JH (1996) FTIR microspectroscopy of particular liptinite-(lopinite-) rich, Late Permian coals from Southern China. Int J Coal Geol 29:187-197

Gupta AK, Chattopadhyay B, Fyfe WS, Powell M (2002) Experimental studies on three potassium-rich ultramafic rocks from Damodar valley, East India. Miner Petrol 74:343-360

Hower JC, Ruppert LF, Eble CF (2007) Lateral variation in geochemistry, petrology, and palynology in the Elswick coal bed, Pike County, Kentucky. Int J Coal Geol 69:165-178

Hower JC, Campbell JL, Teesdale WJ, Nejedly Z, Robertson JD (2008) Scanning proton microprobe analysis analysis mercury and other trace elements in Fe-sulfides from Kentucky coal. Int J Coal Geol 75:88-92

Ibarra JV, Muñoz E, Bonet AJ, Moliner R (1996) FTIR study of the evolution of coal structure during the coalification process. Org Geochem 24:725-735

International Energy Agency (IEA), Key World Energy Statistics 2014. http://www.iea.org/publications/freepublications/publica tion/keyworld2014.pdf. Accessed 12 Dec 2015

Karayigit AI, Gayer RA, Ortac FE, Goldsmith S (2001) Trace elements in the Lower Pliocene fossiliferous Kangal lignites, Sivas, Turkey. Int J Coal Geol 47:73-89 
Li B, Zhuang X, Li J, Querol X, Font O, Moreno N (2016) Geological controls on mineralogy and geochemistry of the Late Permian coals in the Liulong Mine of the Liuzhi Coalfield, Guizhou Province, Southwest China. Int J Coal Geol 154-155:1-15

Miller RT, Given PH (1978) A geochemical study of the inorganic constituents in some low-rank coals. US Department Energy Report FE-2494-TR-1, p 314

Mohanty JK, Mishra SK, Nayak BB (2001) Sequential leaching of trace elements in coal: a case study from Talcher coalfield, Orissa. J Geol Soc India 58:441-447

Mukherjee S, Srivastava SK (2005) Trace elements in high-sulfur Assam coals from the Makum coalfield in the Northeastern Region of India. Energy Fuel 19:882-891

Mukherjee KN, Raja Rao CS, Datta NR, Chowdhury AN, Paul JC, Das M (1981) Salient observations on the trace element studies of some major Tertiary and Gondwana coalfields of India. Ind Miner 35:33-34

Mukherjee KN, Dutta NR, Chandra HS, Pandalai HS, Singh MP (1988) A statistical approach to the study of the distribution of trace elements and their organic.inorganic affinity in Lower Gondwana coals of India. Int J Coal Geol 10:99-108

Murakami K, Ozaki J, Nishiyama Y (1995) Effects of surface treatment on cation exchange properties of Australian brown coals. Fuel Process Technol 43:95-110

Pareek HS, Bardhan B (1985) Trace elements and their variation along seam profiles of certain coal seams Middle and Upper Barakar formations (Lower Permian) in east Bokaro coalfield, district Hazaribagh, Bihar, India. Int J Coal Geol 5:281-314

Sahoo PK, Tripathy S, Panigrahi MK, Eqeenuddin SM (2014) Geochemical characterization of coal waste rocks from a high sulfur bearing coalfield, India: implication for acid and metal generation. J Geochem Explor 145:135-147

Saikia BK, Boruah RK, Gogoi PK (2007) FT-IR and XRD analysis of coal from Makum coalfield of Assam. J Earth Syst Sci 116:575-579

Seredin V, Finkelman RB (2008) Metalliferous coals: a review of the main genetic and geochemical types. Int J Coal Geol 76:253-289
Singh RM, Singh MP, Chandra D (1983) Occurrence, distribution and probable source of the trace elements in Ghugus coals, Wardha valley, district Chandrapur and Yeotmal, Maharashtra, India. Int J Coal Geol 2:371-381

Singh AK, Singh PK, Singh MP, Banerjee PK (2015) Utilization of the Permian Coal Deposits of West Bokaro, India: a petrochemical evaluation. Energy Sources, Part A 37(10):1081-1088

Swaine DJ (1980) Nickel in coal and fly ash. In: Nriagu JO (ed) Nickel in the environment. Wiley, New York, pp 67-92

Swaine DJ (1990) Trace elements in coal. Butterworths, London

Swaine DJ (1995) The content and some related aspects of trace elements in coals. In: Swaine DJ, Goodarzi F (eds) Environmental aspects of trace elements in coal. Kluwer Academic, Dordrecht, p 5

Szilagyi M (1971) The role of organic material in the distribution of Mo, V and Cr in coal fields. Econ Geol 66:1075-1078

Wang J, Sharma A, Tomita A (2003) Determination of the modes of occurrence of trace elements in coal by leaching coal and coal ashes. Energy Fuel 17:29-37

Wedepohl KN (1995) The composition of the continental crust. Geochim Cosmochim Acta 59:1217-1232

Yudovich YE, Ketris MP (2005) Toxic Trace elements in coal. Ekaterinburg. Komi Scientific Center/Institute of Geology/Ural Division, RAS, pp 1-655 (in Russian)

Yudovich YE, Ketris MP (2006) Valuable trace elements in coal. Ekaterinburg. Komi Scientific Center/Institute of Geology/Ural Division, RAS, pp. 1-538(in Russian)

Zhao F, Ren D, Zheng B, Hu T, Liu T (1998) Modes of occurrence of arsenic in high-arsenic coal by extended X-ray absorption fine structure spectroscopy. Chin Sci Bull 43:1660-1663

Zhou J, Zhuang X, Alastuey A, Querol X, Li J (2010) Geochemistry and mineralogy of coal in the recently explored Zhundong large coal field in the Junggar basin, Xinjiang province, China. Int $\mathbf{J}$ Coal Geol 82:51-67 